\title{
触 New Disease Reports \\ Association of Cotton leaf curl Multan virus and its satellite molecules with leaf curl disease of papaya in India
}

\author{
V. Sinha ${ }^{1}$, A. $\operatorname{Kumar}^{2,3}$, D. Bhatnagar ${ }^{1}$ and J.A. $\operatorname{Khan}^{4}$ \\ ${ }^{1}$ Department of Biochemistry, Devi Ahilya University, Indore, India; ${ }^{2}$ Plant Molecular Virology Laboratory, CSIR-National \\ Botanical Research Institute, Rana Pratap Marg, Lucknow-226001, India; ${ }^{3}$ School of Life Sciences, Jawaharlal Nehru \\ University, New Delhi-110067, India (present address); ${ }^{4}$ Department of Biosciences, Jamia Millia Islamia, New \\ Delhi-110025, India
}

*E-mail: vartika.sinha2009@gmail.com

Received: 08 Aug 2012. Published: 06 Mar 2013. Keywords: Carica papaya, begomovirus, leaf curling, satellites

Papaya (Carica papaya) is an important food crop cultivated in the tropical and subtropical countries of the world. Leaf curl disease has become a serious problem in the papaya growing areas of eastern Uttar Pradesh, India. An outcome of the survey for this study showed that this disease occurs consistently in this region and becomes more severe during October to March each year. In order to characterise leaf curl disease of papaya, leaves of four plants with symptoms and one without symptoms were collected during February and March 2010 (Fig. 1). Total DNA was isolated from the leaves, and PCR was used to amplify the geminivirus genomes (Kumar et al., 2011) and their associated satellites (Bull et al., 2003; Kumar et al., 2010), which were then further cloned and sequenced. The full-length sequence for the monopartite begomovirus (DNA-A; 2725 nts) (GenBank Accession JN558352), shared highest nucleotide pairwise identity (96\% BLAST, NCBI) with Cotton leaf curl Multan virus (CLCuMV) reported from Pakistan (AJ002459) and the phylogenetic analyses confirmed the relationship with other CLCuMV isolates (Fig. 2).

The alphasatellite DNA (DNA1, $1390 \mathrm{nts}$ ) (JQ322970) shared 92\% nucleotide pairwise identity with Gossypium darwinii symptomless alphasatellite of Pakistan (FJ218493) and the phylogenetic tree revealed that it grouped with other Cotton leaf curl Multan alphasatellite (CLCuMD1) isolates (Fig. 3). The betasatellite molecule (1371 nts, JX217745) shared highest nucleotide sequence identity ( $>90 \%)$ with Cotton leaf curl Multan betasatellite (CLCuMB) from India (AY744380) and the phylogenetic analyses showed its close relation to other CLCuMB isolates (Fig. 4). According to ICTV guidelines for begomoviruses (Fauquet et al., 2008), and betasatellites (Briddon et al., 2008) the virus under study is considered as an isolate of CLCuMV and the betasatellite as an isolate of CLCuMB.

Rolling circle amplification (RCA) was performed (TempliPhi amplification kit; GE Healthcare, USA) to construct infectious clones. RCA products were partially digested with $\mathrm{BamHI}$ to obtain monomer and head-to-tail tandem repeat dimers of full-length begomovirus DNA. Monomers and dimers were cloned into the pCAMBIA2301 vector. An infectious head-to-tail tandem repeat clone of the betasatellite was prepared similarly. Sequencing of 10 DNA-A monomer clones confirmed the presence of identical viral DNAs. Infectivity testing was performed by single and combined inoculation of tobacco (10 plants in each case) with Agrobacterium as a carrier of the begomovirus (DNA-A) or the betasatellite infectious construct. Only the plants infected with DNA-A and betasatellite showed leaf curling symptoms, whereas the others exhibited no symptoms. The data strongly supports association of CLCuMV and associated satellites with leaf curl disease of Papaya in India.

\section{Acknowledgements}

The authors are thankful to Director, CSIR-NBRI for providing necessary facilities. The second author is thankful to UGC-CSIR for fellowship.

\section{References}

Briddon RW, Brown JK, Moriones E, Stanley J, Zerbini M, Zhou X, Fauquet CM, 2008. Recommendations for the classification and nomenclature of the DNA- $\beta$ satellites of begomoviruses. Archives of Virology 153, 763-781. [http://dx.doi.org/10.1007/s00705-007-0013-6]

Bull SE, Briddon RW, Markham PG, 2003. Universal primers for the PCR-mediated amplification of DNA 1: A satellite-like molecule associated with begomovirus-DNA $\beta$ complexes. Molecular Biotechnology 23, 83-86. [http://dx.doi.org/10.1385/MB:23:1:83]

Fauquet CM, Briddon RW, Brown JK, Moriones E, Stanley J, Zerbini M, Zhou X, 2008. Geminivirus strain demarcation and nomenclature.

Archives of Virology 153, 783-821.

[http://dx.doi.org/10.1007/s00705-008-0037-6]

Kumar A, Kumar J, Khan ZA, Yadav N, Sinha V, Bhatnagar D, Khan JA, 2010. Study of beta satellite molecule from leaf curl disease of Sunn hemp (Crotalaria juncea) in India . Virus Genes 41, 432-440.

[http://dx.doi.org/10.1007/s11262-010-0531-2]

Kumar A, Snehi SK, Raj SK, Kumar J, Khan JA, 2011. Association of Cotton leaf curl Burewala virusand its satellite molecules with leaf distortion symptoms of cotton in India. New Disease Reports 24, 18. [http://dx.doi.org/10.5197/j.2044-0588.2011.024.018]

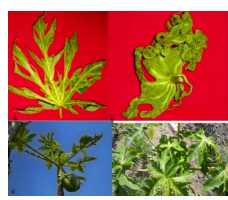

Figure 1

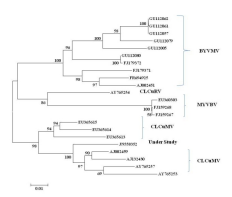

Figure 2

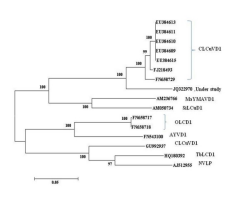

Figure 3

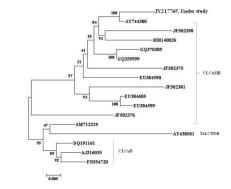

Figure 4

To cite this report: Sinha V, Kumar A, Bhatnagar D, Khan JA, 2013. Association of Cotton leaf curl Multan virus and its satellite molecules with leaf curl disease of papaya in India. New Disease Reports 27, 9. [http://dx.doi.org/10.5197/j.2044-0588.2013.027.009]

(c) 2013 The Authors

This report was published on-line at www.ndrs.org.uk where high quality versions of the figures can be found. 